\title{
An Analysis of Grammatical Errors in Writing Recount Texts by the Tenth Graders
}

\section{Analisis Kesalahan Tata Bahasa dalam Penulisan Teks Recount oleh Siswa Kelas 10}

\author{
Bella Rizky Amelia, Sri Rachmajanti*, Mirjam Anugerahwati \\ Universitas Negeri Malang, Jl. Semarang No. 5 Malang, Jawa Timur, Indonesia \\ *Penulis korespondensi, Surel: sri.rachmajanti.fs@um.ac.id
}

Paper received: 02-01-2021; revised: 15-01-2021; accepted: 30-01-2021

\begin{abstract}
This study was conducted to analyze the grammatical errors in writing recount texts by the tenth graders. A table analysis and a questionnaire were being used in this study. The data was analyzed based on the surface strategy taxonomy that was adapted from Dulay, Burt, and Krashen (1982). The errors were classified into four categories; omission, addition, misformation, and misordering. The subject was 24 students. This study used a qualitative method which was a descriptive analysis. There were some instruments in this study; the writing task, the table of analysis, the questionnaire and the scoring formula. The result of this study shows that the students still made grammatical errors in writing the recount text. There are 447 errors in the students' writing. Misformation error becomes the most common error with a frequency 190 errors (42.5). Then, it was followed by 162 omission errors (36.3\%), 86 addition errors (19.2\%), 9 misordering errors (2.0\%). The questionnaire findings indicate that most students did not understand how to apply the grammar rules in their writings and teachers need to give more explanation how to apply the grammar rules in writing.
\end{abstract}

Keywords: grammatical errors, recount text, tenth graders

\begin{abstract}
Abstrak
Penelitian ini bertujuan untuk menganalisis kesalahan tata bahasa dalam penulisan teks recount oleh siswa kelas 10. Penelitian ini menggunakan tabel analisis dan kuesioner. Data dianalisis dengan berdasarkan surface strategy taxonomy yang dikemukakan oleh Dulay, Burt, and Krashen (1982). Kesalahan-kesalahan yang ada dibagi menjadi empat kategori; omission, addition, misformation, dan misordering. Subyek penelitian terdiri dari 24 siswa. Penelitian ini menggunakan metode kualitatif, lebih tepatnya analisis deskriptif. Instrumen yang digunakan antara lain; tugas menulis, tabel analisis, kuesioner, dan rumus skoring. Hasil penelitian menunjukkan bahwa siswa masih membuat kesalahan dalam menulis teks recount. Terdapat 477 kesalahan dalam tulisan siswa. Kesalahan misformation menjadi kesalahan yang paling umum dengan frekuensi sebanyak 190 kesalahan $(42,5 \%)$, diikuti oleh kesalahan omission sebanyak 162 (36,3\%), kesalahan addition sebanyak 86 $(19,2 \%)$, dan kesalahan misordering sebanyak 9 (2,0\%). Menurut kuesioner, kesalahan ini masih terjadi karena kebanyakan siswa masih bingung mengenai penerapan tata bahasa dalam tulisan mereka. Oleh sebab itu, guru dianjurkan untuk menjelaskan lebih jauh mengenai cara penerapan tata bahasa dalam menulis.
\end{abstract}

Kata kunci: grammatical errors; recount text; siswa kelas X

\section{Introduction}

Mastering English has become the most essential part of people's lives. By mastering English, there are many things we can do. Besides using technology, communicating with other people from different countries around the world is accessible. The key is using English. As English is an international language, it is easier to communicate with other people who have different languages using English. There are four skills in English that need to be learned by 
students, especially for EFL students in Indonesia. Since English has become a compulsory subject in secondary school, it means that English is one of the criteria for the students to pass one semester. Those skills are listening, reading, speaking and writing. Writing skill is important to be taught for EFL students. Since writing belongs to productive skills, writing is considered a difficult skill. According to Fareed, Ashraf, and Bila (2016), an essential skill is writing in language production. The reason is because the students need to produce something that is related to the knowledge they have got. It is important to teach the students how to write academic writing. It is in line with what Harmer (2004) has said that writing has to be taught. Writing needs many preparations, such as thinking about the idea and how to address it (Oshima \& Hogue, 2017). It can be seen that writing does not come out naturally. Kumala, Aimah, and Ifadah (2018) mentioned that EFL students need a lot of practice in order to make their writings meaningful. In line with that statement, Cheung (2016) stated that the writing activity is complicated. In fact, writing is different from other skills. Compared with speaking, it is more spontaneous. On the other hand, writing needs preparation. Dewi $(2014,66)$ mentioned that "Writing as one of the language skills at any level of education that has to be mastered is rather difficult than other skills". The main reason is that when the students have to write something, they have to master the other skills. It can be said that writing is the result of combining other skills.

In school, the students need to write a text. It is called an academic text. Academic writing is the kind of writing that is different from any other kind of writing. Oshima and Hogue (2007) mentioned that it is essential to write academic writing in a certain way because academic writing belongs to formal writing. Therefore, it is important to teach how to write academic writing for EFL students. Moreover, writing does not come out naturally. Harmer (2004) mentioned that writing has to be taught. It is different from speaking which has been exposed since childhood. The journey of learning is similar to a child's learning which starts with listening, speaking, reading, and writing (Dewi, 2014). It can be seen that writing is the last stage of the learning sequence. It means that the students need to master other skills in order to master the writing skill. Therefore, writing is important to learn, especially for EFL students. Kumala, Aimah, and Ifadah (2018) maintained that EFL students need a lot of practice in writing to make it meaningful. It can be said that writing skill needs to be trained in order to get a well-written text.

There is a process in writing. The students need to understand the process before doing the real writing. According to Oshima and Hogue (2007), there are four steps in the process of writing; prewriting, organizing, writing and polishing. Producing a good text takes a lot of time. The reason is because writing is a combination of hard thinking and good grammar (Sadiah \& Royani, 2019). In line with that statement, Brown and Lee (2015) stated that writing is the result of thinking, drafting and revising.

Before producing the text, the students need to master the English components. Those are vocabulary and grammar. Writing activity and English components are related to each other. The writing activity would not be finished if the students are not mastering the English components. The researcher believes that the most important component is grammar. In line with that statement, Kumala, Aimah, and Ifadah (2018) mentioned that the process of writing needs broad knowledge to create sentences and paragraphs with good English grammar at the same time. Based on Sadiah and Royani (2019), writing and grammar are linked to each other and cannot be separated. In addition, they mentioned that mastering grammar rules will make 
their writings easy to understand. Similarly, Putri and Dewanti (2014) argued that if the students want to deliver their ideas well, they need to make a text which is grammatically correct. It can be seen that mastering grammar rules is the important part to have a good text.

However, mastering grammar rules is not easy, especially for EFL students. Since English grammar rules and Bahasa Indonesia are different, English grammar becomes the most difficult part of writing. Based on Liasari (2017) it is hard to apply grammar in writing. She also mentioned that grammar is confusing rules. In addition, grammar has many branches. It is understandable if errors in grammar are easily found in students' writings. Therefore, grammatical errors become a common thing in writing. The meaning of error itself is different from a mistake. Errors happen when the students lack the knowledge. On the other hand, mistakes occur due to the students' negligence, such as being sleepy and sick. The mistakes are related to the students' performance. In line with the statement, Kumala, Aimah, and Ifadah (2018) stated that the reason why the grammatical errors occur is that the students do not understand enough about the grammar rules. The meaning of error is different from a mistake. Errors occur when the students still lack the knowledge. On the other hand, mistakes are related to the performance and appear due to the students' negligence. Novita (2014) also mentioned that errors happen unconsciously. It means that when the students make some errors in their writings, they do not realize it. She added that it will be difficult for the readers to understand the idea of their writing if the students make many grammatical errors.

The fact that writing in English is different from writing in Bahasa Indonesia, the students find it difficult. They tend to translate their ideas directly into English without understanding the right rules. The example is when the student wants to write "aku suka makan nasi goreng", he/she would go like "I like eat rice fried" instead of "I like eating fried rice". Novita (2014) stated that Indonesian students tend to apply Indonesian's rules when they use English. In addition, Nabila (2018) mentioned the difference between L1 and L2. She maintained that there is no verb transformation in L1 (Bahasa Indonesia) while tenses in English require verb transformation that is used to show the adverb of time.

It can be one of the reasons why grammatical errors appear in the students' writings. The same problem occurs in the 10th graders of SMAN 8 Malang. Based on the interview with the English teacher, the students had difficulties in grammar. It is proven by the researcher who found the grammatical errors in the students' writings. The students wrote a recount text at that time. Some students used the wrong tenses in writing the recount text. It can be seen that grammatical errors still appear in the students' writing. The example is the use of the wrong verb. For example, instead of expressing "I ate some bread yesterday", the students wrote, "I eat some bread yesterday". As in writing the recount text, it has to use the past tense. Based on Curriculum 2013, the recount text is one kind of text which has to be learned in Grade 10. The students are also required to produce their own text. As it is stated in the Basic Competence of 4.7.2 "Produce a short and simple recount text in written and spoken forms which is related to a historical event using the correct social function, text structure and linguistic elements" (Menyusun teks recount lisan dan tulis, pendek dan sederhana, terkait peristiwa bersejarah, dengan memperhatikan fungsi sosial, struktur teks, dan unsur kebahasaan, secara benar dan sesuai konteks). The grammar points in the recount text cover the simple past tense, adjective, adverb of time, adverbial clause, and adverbial phrase as they are stated in the English book for grade 10 entitled "Bahasa Inggris" (2017). 
This study used surface strategy taxonomy to classify the errors. It was adapted by Dulay, Burt, and Krashen (1982). There are four categories in the surface strategy taxonomy. There is omission, addition, misformation, and misordering. Omission errors happen when the students omit a grammatical aspect which has to appear in a sentence. It can be a noun, verb or even article and prepositions. Different from omission, addition errors are the opposite of omission errors. Additional errors occur when the students add an unnecessary grammatical aspect in a sentence. There are three types of addition; double marking, regularization, and simple addition. The third category is misformation errors. It happens when the students use the wrong form of a grammatical aspect. There are three types of misformation; regularization, archi-form, and alternating-form. The last category is misordering. It means the incorrect placement of a grammatical aspect in a sentence. It can be caused by the students' translation which uses the L1 rules instead of the L2 English.

Considering the explanation above, the purposes of this study are to find the kinds of grammatical errors in writing the recount text by the tenth graders in SMAN 8 Malang and to know the factors that affect the students in making grammatical errors in writing the recount text. It is important to know the grammatical errors made by the students. Teachers can be more concerned about the students' grammar. Also, the teachers need to give more opportunities to the students to do writing practice. By practicing, the students will know how to write a good text with the right grammar rules.

\section{Method}

This study used a qualitative method which was a descriptive analysis. Hikmawati (2018) mentioned that the descriptive analysis was used to collect some information about something without making any conclusion. Sadiah and Royani (2019: 765) stated that "the goal of descriptive research is to describe a phenomenon and its characteristics". They also mentioned that this method was more focused on what has happened. The grammatical errors were analyzed based on the surface strategy taxonomy that was adapted by Dulay, Burt, and Krashen (1982). This study analyzed the grammatical errors made by the 10th graders in writing the recount text. The grammatical errors were classified into 4 categories. There were omission, addition, misformation, and misordering. After classifying the errors, the result of this study was presented in the form of words and percentages. It was used to see the frequency of each type of error.

The study was conducted in SMAN 8 Malang. The school was chosen because it is one of the qualified schools in Malang. It is shown in the output of the National Exam (UN) scores in Malang of the academic year of 2018/2019. Four students got 100 on their English exams. In addition, it can be seen that many graduate students were accepted into public universities without taking any test. Also, there are many achievements in both academic and nonacademic.

The subjects of this study were the 10th graders of SMAN 8 Malang. To be specific, the researcher chose Science 6 consisting of 29 students. However, there were 24 students' writing. The reason was because five students did not do the task. The students' competence was fair to good. It was shown in their scores that most of the students passed the minimum score (75) with the percentage of $80 \%$. Also, they felt excited when they learned English. The students learned online using Google meets application due to the current situation. However, the students still had a problem in learning English, especially in writing a recount text. Based 
on the teacher, the students had difficulty in applying grammar, particularly tenses, in their writings. Therefore, an analysis of grammatical errors was needed to know which aspects that became the problem.

Some instruments were used for collecting the data in this study. There were the writing task, the table of analysis, the questionnaire and the scoring formula. The researcher collected the data from the English teacher. She had already asked the students to write a short recount text. She sent the writing prompt through WhatsApp and asked the students to write one simple recount text using the correct text structure. Collecting the data had been done online since the school was closed due to the Covid-19. On 9th September 2020, the researcher collected the students' writing from the English teacher.

The researcher used the table of analysis in this study to classify the errors. After getting the students' writing, the researcher analyzed the students' writing based on the table of taxonomy. The researcher classified the errors into each category. The categories were omission, addition, misformation, and misordering. After that, the collected data was presented in the form of words and percentages. It was also used to see the frequency of errors in each category.

In addition, the researcher wanted to know what factors that affect the students in making grammatical errors in their recount texts. Thus, a questionnaire was being used in this study. The questionnaire was related to the cause of making errors in writing a recount text. The students had filled the questionnaire after writing the recount texts. In addition, the students had filled the questionnaire online. Therefore, the researcher analyzed the questionnaire by converting the results to the percentage. It was easier to see the students' opinions.

The last instrument was the scoring formula. It was used to score the result of analysis. The researcher tabulated the data after classifying them. The scoring formula was meant to see the frequency of errors in each category.

\section{Result and Discussion}

\subsection{The result of the writings}

There are 447 errors found in the students' writing. It consists of 162 errors in omission, 86 errors in addition, 190 errors in misformation, and 9 errors in misordering. The total number and its percentage are shown in Table 1

Table 1 Frequency of each type of errors

\begin{tabular}{lll}
\hline Type of Error & F & Percentage (\%) \\
\hline Omission & 162 & $36.3 \%$ \\
Addition & 86 & $19.2 \%$ \\
Misformation & 190 & $42.5 \%$ \\
Misordering & 9 & $2.0 \%$ \\
Total & 447 & $100 \%$ \\
\hline
\end{tabular}

The result showed that misformation errors became the most frequent errors in the data analysis with 190 errors (42.5\%). Misformation happened when the students used the wrong form of a grammatical aspect in a sentence. Since the students needed to write the recount text using the past tense, choosing the right tenses with various forms could be confusing for the 
students. From the data analysis, the researcher found that the common errors were the wrong form of auxiliaries.

There were some examples from the data analysis. The sentence "I still have to do some works from school online. (S2)" was incorrect. The auxiliary 'have' should be in the form of past tense. It was because the student needed to write a recount text. Therefore, the auxiliary 'have' should be replaced by 'had'. "I still had to do some works from school online" is the right form. The second example was in the sentence "There are 4 experiences to avoid covid-19, the first is studying at home. (S8)". There were 2 errors of auxiliary in this sentence. Both of them were the forms of be. Since the student had to write the recount text, he had to use the simple past tense. Therefore, the forms of 'are' and 'is' should be changed into 'were' and 'was'. The correct form is "There were 4 experiences to avoid the covid-19, the first was studying at home"'. The third example was in the sentence "To made those videos, I needed a long time. (S3)". The student put an infinitive maker 'to' that had to be followed by an infinitive verb. However, the student used the past tense 'made' and it was wrong. The researcher decided to change it into 'make'. "To make those videos, I needed a long time" is the correct form.

The second category was omission errors. Omission happened when grammatical aspects were missing. The researcher found 162 omission errors in the students' writing. The most frequent errors were omission of verb inflections. There were 51 errors in the data analysis. There were some examples from the students' writing. In the sentence 'Sleep during day can boost my immune. (S5)", there were some errors in the first sentence. Here, the student used the word 'sleep' was in the wrong form. It should be in the form of a gerund. It was because the verb was used as a subject. Therefore, the researcher decided to add -ing in the word 'sleep' and became 'sleeping'. "Sleeping during the day could boost my immune" is the correct form. The second example was in the sentence "At Monday morning, the headmistress announce the home-learning policy. (S10)". Since the students were asked to write a recount text, they had to use the simple past tense. The verb 'announce' should be in the form of past tense. The student omitted the -ed in this sentence. The correct verb in this sentence was 'announced'. The correct form is "On Monday morning, the headmistress announced the home-learning policy". The third example was in the sentence "If we bought fruits, we need to washed them off with foodgraded soap. (S23)". In this sentence, the student used the infinite form of 'need'. The student omitted the -ed in the verb 'need' like the previous sentence. Therefore, the researcher added -ed to correct the error. "If we bought fruits, we needed to wash them off with food-graded soap" is the correct form.

The third category was additional errors. Errors in addition happened when the students added some grammatical aspects that were not needed in their writings. The researcher found 85 errors of addition. The most frequent errors were the simple addition of verb inflection that occurred 32 times in the data analysis. These errors happened when the students added unnecessary verb inflections in their writings. The example was in the sentence "I started to exercise and eating healthy foods ... (S12)". The word 'eating' was not in the right form. The student added -ing when it should be 'eat'. It was because there was a conjunction 'and' to connect the verbs that had the same grammatical form. The correct form is "I started to exercise and eat healthy foods ...". The second example was in the sentence "Because the virus was spreaded, so all the students in SMAN 8 Malang studied at home started March 23th. (S6)". The verb 'spread' was in the wrong form in this sentence. The word 'spread' had the same form in its infinitive and past tense. However, the student added the -ed to make it past tense. 
Therefore, the researcher omitted the -ed to correct it. The correct form is "Because the virus spread, all the students in SMAN 8 Malang studied at home starting March 23rd."

The last category was misordering errors. Misordering happened when the placement of a grammatical aspect was incorrect. This type of errors was the least frequent in the students' writing. It was found 9 errors of misordering. The misordering of the subjects was found 6 times in the students' writing. It became the most frequent errors in the data analysis. The example was in the sentence "But, when I watched the news on tv about the worsening of the virus, me and my family started to bought some home supplies. (S21)". The student made some errors in this sentence. Here, the pronoun 'me' was not suitable to be used as a subject. The researcher decided to change 'me' to 'I'. After that, the placement of the subject was incorrect. The researcher categorized as a misordering of the subject. The student wrote 'me and my family' instead of 'my family and I'. The correct form is "But, when I watched the news on TV about the worsening of the virus, my family and I started to buy some home supplies". The second example was in the sentence "At first I was happy because my expectations of being able to relax turned out, the next day to become many taks". The adverb of time was shown by the noun phrase "the next day". However, the adverb of time was in the wrong place. The researcher decided to move the adverb into the last sentence. The revision is "At first, I was happy because my expectations of being able to relax turned out to have many tasks the next day."

\subsection{The Result of the Questionnaire}

The data of the students' perceptions were obtained through a questionnaire. It was distributed to 24 students. The students filled the questionnaire online. The purpose of filling the questionnaire was to find out the factors that affected the students in making grammatical errors in writing the recount texts. The questionnaire consisted of 6 questions. The result of the questionnaire was calculated using percentages. It was easier to see the students' opinions.

After calculating the data, it showed that all the students had experienced writing a recount text. Most of the students thought that their writings were fair with the percentage of $79.2 \%$. They agreed that grammar became the biggest challenge in writing the recount texts. For the question 5 about whether or not the simple past tense became the difficulty for the students in writing the recount texts, the data showed that most of the students had no difficulty in writing the recount texts using simple past tense with the percentage of $62.5 \%$. However, the data showed that the students still had problems in writing the recount texts using simple past tense.

As it was stated above that the biggest problem for the students was grammar, the students thought that the reason why grammar is difficult was because the students were still confused about how to apply the grammar rules. It showed $45.8 \%$ that the students were difficult in applying the grammar rules in their writings. For question 6 about the way the students learn grammar, half of the students chose to learn grammar from online applications.

It can be seen that most of the students chose using online grammar checkers as a solution for their problem, which is grammar. It was because using online grammar checkers was more accessible than any other options. The students could use it anywhere and anytime.

\subsection{Discussion}


The research problem in this study was to know the kinds of grammatical errors found in writing the recount texts by the tenth graders in SMAN 8 Malang. From the results of the analysis, there were various types of errors. The researcher found 447 errors in the writings of 24 students.

There were some challenges in doing this study. The fact that the students had done the task online due to the current condition (Covid-19), the result of the students' writings were not quite satisfying. It was shown by the errors that the students made in their writings. Another reason was because the students had to experience the online class. It made the students have a limitation to ask about the materials.

While doing this study, it was found that the errors could belong to more than one category in one sentence. It was because each error had different criteria. In this study, the misformation category had the highest frequency. Misformation errors happened 190 times in the students' writings with the percentage of $42.5 \%$. This category consisted of the errors in regularization, archi-form and alternating-form. According to Dulay, Burt and Krashen (1982), they mentioned that the students in the intermediate stages, misformation were likely to happen because they have been exposed to more English. It is in line with the result of this study, in which the students were not in the early stages, the misformation errors became the most frequent errors. The researcher believed that choosing the right tenses with various forms could be confusing for the students.

The same result also happened in Sari's study (2019). She also used the surface strategy taxonomy to classify the errors made by the eleventh graders of SMKN 1 Abung Selatan. From the result, it was found that the most frequent errors were misformation errors. The errors were found 117 times in the students' writing. She mentioned that the students' understanding of the past tense was low. It was the reason why the students made the misformation errors.

It was also in line with the previous studies conducted by Rusmiati (2019) that the misformation errors became the most frequent errors in her study. The errors were found 62 times in the misformation errors with the percentage of $72.94 \%$. Since she analyzed narrative paragraphs, the students should use the past tense. However, she found that most verbs in the data analysis were not in the form of past tense. It can be seen that the students were still confused whether they had to use the infinitive form or the past tense.

In contrast with this finding, the studies conducted by Kumala, Aimah, and Ifada (2018) and Alfiyani (2013) found that omission errors were the most frequent errors in their studies. They mentioned that the errors were mostly about the omission of linguistic words, morphemes, and phrases in their data analysis. Alfiyani (2013) found 281 omission errors with a percentage of $47.22 \%$. While Kumala, Aimah, Ifada (2018) found 300 omission errors from the total 810 errors made by 27 students of University of Muhammadiyah Semarang with the percentage of $37 \%$. They mentioned that carelessness became the main factor in making grammatical errors in their study.

The omission errors became the second most frequent in this study. From the data analysis, it showed the percentage of the omission errors $36.3 \%$. The omission of grammatical morphemes happened to be the most frequent errors. It was in line with what Dulay, Burt, and Krashen (1982) mentioned that the most common errors were the omission of the grammatical morphemes. They stated that the students made errors by omitting the grammatical 
morphemes more frequently than content words. The grammatical morphemes included the articles and the verb inflections which had a minor role but influenced the meaning. Since the students omitted the grammatical morphemes, it can be seen that they omitted unconsciously.

The addition errors reached $19.2 \%$ in this study. The errors happened 86 times in the students' writings. The most frequent errors were in simple addition. The same result happened in Alfiyani's study (2013). In her study, simple addition reached the highest percentage $14.11 \%$. The errors happened 84 times out of 119 errors.

The misordering errors were found to be the lowest frequent errors with the percentage of 2.0\%. The errors occurred 9 times in the data analysis. The most frequent errors were the misordering of subjects. The errors happened 6 times. Different from the result of this study, Fridayanthi (2017) and Sari (2019) found that the least frequent errors in their study were addition errors. The study conducted by Fridayanthi (2017) found the addition errors happened 12 times with the percentage of 7.1\%. While in Sari's study (2019), the addition errors happened to be the lowest frequent errors with the percentage of $1.4 \%$.

In relation to the errors that had been elaborated above, the researcher referred to the result of the questionnaire. More than half of the students remarked that they had no difficulty in writing a recount text using the simple past tense. However, it was not in line with the result of the analysis. It could be seen above that the most frequent errors happened in misformation, especially in alternating-forms which were using the wrong selection of a word in various members of a class.

In addition, the students admitted that grammar became their problem in writing the recount texts. They mentioned that the reason why grammar was difficult was because they still could not apply the grammar rules in writing a recount text. It was supported by the study conducted by Sari (2019). She mentioned that the students made grammatical errors because they still did not master the grammar rules. In line with that statement, Rusmiati (2019) stated that the grammar rules in Bahasa Indonesia and English are different. In Bahasa Indonesia, no tenses are used to tell the present or past. While in English, there are rules that have to be paid attention to.

\section{Conclusion}

Based on the findings in this study, it can be concluded that the tenth graders of Science 6 in SMAN 8 Malang still have some difficulties in writing the recount texts. The most difficult part is the grammar. It can be seen from the grammatical errors that the students made in their writings.

The students' writing was analyzed by using the surface strategy taxonomy which was adapted from Dulay, Burt, Krashen (1982). It is found that the most errors are in the misformation category. From the data analysis, 190 errors of misformation were indicated. It occurs when the students input a grammatical error, but it is in the wrong form. In this study, the wrong forms of auxiliary happen to be most errors in misformation.

It was found that the least errors are in the misordering category. Misordering occurs when the students put grammatical aspects in the incorrect place. The study found 9 errors of misordering. Some errors are influenced by Indonesian rules. It can be seen that the students translated directly from Bahasa Indonesia to English without considering the grammar rules. 
From the result of the questionnaire the main factor that affects the students in making grammatical errors is they still could not understand how to apply the grammar rules in writing the recount texts.

It is suggested that teachers pay more attention to the students' grammar. It is good if the students have a writing schedule. The students are asked to write a weekly journal as a writing practice. Therefore, the students can understand more about grammar and apply the correct grammar in their writings. Due to the limitations of this study, it is not complete yet and cannot cover all aspects of grammar. Thus, the researcher suggests that future researchers conduct similar studies using different methods. In addition, it is good if the future researchers find an effective way to help the students in understanding grammar.

\section{References}

Brown, H. D. \& Lee, H. 2015. Teaching by principles, Fourth edition. New York: Pearson Education.

Cheung, Y. L. (2016). Teaching writing. In W. A. Renandya, \& H. P. Widodo (Eds.), English language teaching today: Building a closer link between theory and practice. New York: Springer International.

Dewi, R. S. (2014). Teaching writing through dictogloss. Indonesian Journal of English Education, 1(1), 65-76.

Dulay, H., Burt, M. \& Krashen, S. D. (1982). Language two. New York: Oxford University Press.

Fareed, M., Ashraf, A. \& Bilal, M. (2016). ESL learners' writing skills: Problems, factors and suggestions. Journal of Education and Social Sciences, 4(2), 81-92.

Harmer, J. (2004). How to teach writing. England: Pearson Education Limited

Hikmawati, F. (2018). Metode penelitian. Depok: Rajawali Pers.

Kumala, P. B., Aimah, S. \& Ifadah, M. (2018). An analysis of grammatical errors on students' writing. English Language and Literature International Conference 2, 144-149.

Liasari, D. T. 2017. An analysis of students' grammatical errors in writing report text at second grade of senior high school. Unpublished Thesis. Lampung: Universitas Lampung.

Nabila, A. (2018). Grammatical errors in writing recount text made by 10th graders. Unpublished Thesis. Malang: FS Universitas Negeri Malang.

Novita, R. (2014). An analysis of grammatical errors in the 1st year students' writings at English Department, Andalas University. Vivid Journal, 3(2), 1-15.

Oshima, A. \& Hogue, A. (2007). Introduction to academic writing. New York: Pearson Education.

Putri, P. S. \& Dewanti, A. (2014). An analysis of grammatical errors in writing narrative texts done by the second semester students at the Diploma Program English Department in Airlangga University Surabaya. Anglicist, 3(1), 1-7.

Rusmiati. (2019). Surface strategy taxonomy on foreign language writing: A study on verb tense usage. Jurnal Serambi Ilmu, 20(2), 189-201.

Sadiah, S. \& Royani, S. A. (2019). An analysis of grammatical errors in students' writing descriptive text. Professional Journal of English Education, 2(6), 764-770.

Sari, T.J. (2019). An analysis of grammatical errors in writing recount text at the eleventh grade of students' SMK Negeri 1 Abung Selatan Kotabumi in the academic year 2018/2019. Unpublished Thesis. Lampung: State Islamic University Raden Intan. 